\title{
Evaluation of the Fate of Ice Storm-Damaged Urban Maple (Acer) Trees
}

\author{
Christopher J. Luley and Jerry Bond
}

\begin{abstract}
Annually, ice storms cause millions of dollars of damage to urban trees and infrastructure in the United States and Canada. However, there is limited information to guide judgments on whether to remove ice-damaged trees. This study followed the response of three maple species that were damaged in the 1998 ice storm in northern New York State. Norway (Acer platanoides), silver (A. saccharinum), and sugar maples (A. saccharum) were placed in one of three diameter classes and canopy loss categories and were reevaluated 6 years after the initial damage. Over the 5-year study period, $26.8 \%$ of trees were removed, and there was no statistical difference among species, crown loss, or diameter class for these removals. Analysis of a variety of tree health and crown parameters showed that tree species was the most important factor in response, whereas diameter class and crown loss were less important. These results suggest that urban tree managers should consider tree species as an important factor in making removal decisions after an ice storm.
\end{abstract}

Key Words. Acer platanoides; Acer saccharinum; Acer saccharum; canopy loss; ice damage; maple species; Norway maple; removal rate; silver maple; sprouting; tree response.

Annually, ice damage to urban trees causes millions of dollars of losses in the United States. In the Northeast, there is a major ice storm once every $\approx 8$ years. Between 2001 and 2004 alone, federal authorities declared 13 ice storm for states in the East and Midwest (FEMA 2005). Each of these storms caused extensive damage to urban trees in addition to requiring a major cleanup effort and causing major utility outages with associated costs often rising into many hundreds of millions of dollars.

Despite the frequent occurrence and extensive damage caused by ice storms, there are no standard long-term recommendations for managing ice-damaged trees in urban areas, although there are many for rural forests (Van Dyke 1999). The Federal Emergency Management Agency (FEMA) will reimburse communities in declared disaster areas for removing trees that have $50 \%$ or greater canopy loss (FEMA 1999), although the basis of that position has not been documented by this agency as far as we have been able to ascertain. Simple guidelines used by many urban forest managers are contained in a two-page fact sheet distributed by the U.S. Department of Agriculture (USDA) Forest Service (Shortle and Smith 1998). In that guide, primarily aimed at rural forest owners, it is suggested that trees with greater than $50 \%$ crown loss will likely decline in the long term. In the short term, ice damage impact is primarily the result of the direct loss of live canopy from stem breakage that will result in low chances for survival (Shortle and Smith 1998a, 1998b). Older studies concluded that extensive canopy loss could cause direct mortality (Spaulding and Bratton 1946; Carvell et al. 1957). More recently, trees with greater than $75 \%$ crown loss have been recommended for immediate removal (Sisinni et al. 1995; Shortle and Smith 1998a, 1998b), and mortality of paper and yellow birch after an ice storm in New England forest ecosystems was attributed to Armillaria root disease killing icedamaged trees (Shortle et al. 2003).

Species vary in their susceptibility to ice storm damage. There are two excellent studies documenting the ice storm damage to different tree species grown under urban conditions in Urbana, Illinois (Hauer et al. 1993) and in Rochester, New York (Sisinni et al. 1995). In these as well as in studies of rural forests, sugar maple (Acer saccharum) is rated as intermediate in susceptibility to ice damage (Downs 1938; Croxton 1939; Lemon 1961; Bruederle and Sterns 1985; Melancon and Lechowicz 1987; Seischab et al. 1993; Hauer et al. 1994; Sisinni et al. 1995). However, in Ontario, Canada, serious damage to sugar maple was observed in some locations in the massive 1998 storm (Irland 1998). Silver maple (A. saccharinum), on the other hand, is usually severely damaged by ice and is rated as susceptible, whereas Norway maple ( $A$. platanoides) is rated as resistant (Hauer et al. 1994; Sisinni et al. 1995).

Recent studies have focused on the differing ability of individual deciduous species to tolerate crown loss. This ability depends on the particular combination of two strategies: 
Table 1. The number of trees in the species by diameter by crown loss matrix that was created to evaluate the effect of ice damage in northern New York.

\begin{tabular}{|c|c|c|c|c|c|}
\hline & \multirow[b]{2}{*}{ Diameter } & \multicolumn{4}{|c|}{ Crown loss categories } \\
\hline & & $1(0 \%-25 \%)$ & $2(26 \%-50 \%)$ & $3(51 \%-75 \%)$ & Total \\
\hline \multirow[t]{4}{*}{ Silver and red maple } & $6^{\prime \prime}-18^{\prime \prime}$ & 26 & 4 & 6 & 36 \\
\hline & $18^{\prime \prime}-30^{\prime \prime}$ & 14 & 18 & 30 & 62 \\
\hline & Over $30^{\prime \prime}$ & 12 & 11 & 22 & 45 \\
\hline & Subtotals & 52 & 33 & 49 & 143 \\
\hline \multirow[t]{4}{*}{ Sugar maple } & $6 "-18^{\prime \prime}$ & 14 & 9 & 9 & 32 \\
\hline & $18^{\prime \prime}-30^{\prime \prime}$ & 22 & 18 & 18 & 58 \\
\hline & Over $30^{\prime \prime}$ & 12 & 13 & 10 & 35 \\
\hline & Subtotals & 48 & 40 & 37 & 125 \\
\hline \multirow[t]{4}{*}{ Norway maple } & $6^{\prime \prime}-18^{\prime \prime}$ & 30 & 23 & 20 & 73 \\
\hline & $18^{\prime \prime}-30^{\prime \prime}$ & 17 & 11 & 10 & 37 \\
\hline & Over $30^{\prime \prime}$ & 1 & 2 & 0 & 3 \\
\hline & Subtotals & 48 & 36 & 24 & 113 \\
\hline Overall totals & & 148 & 109 & 123 & 381 \\
\hline
\end{tabular}

compartmentalization of decay and resprouting of lost crown; the latter strategy is almost completely lacking in coniferous species (Van Dyke 1999; Smith and Shortle 2003). In contrast, white ash in northeastern forests recovers from near total crown loss with minimal long-term effects (Shortle et al. 2003; Smith and Shortle 2003). Sugar maple has a good compartmentalization response but sprouts minimally such that it cannot replace lost crown (Spaulding and Bratton

Table 2. Data collected during the resurvey of ice storm-damaged trees in 2004.

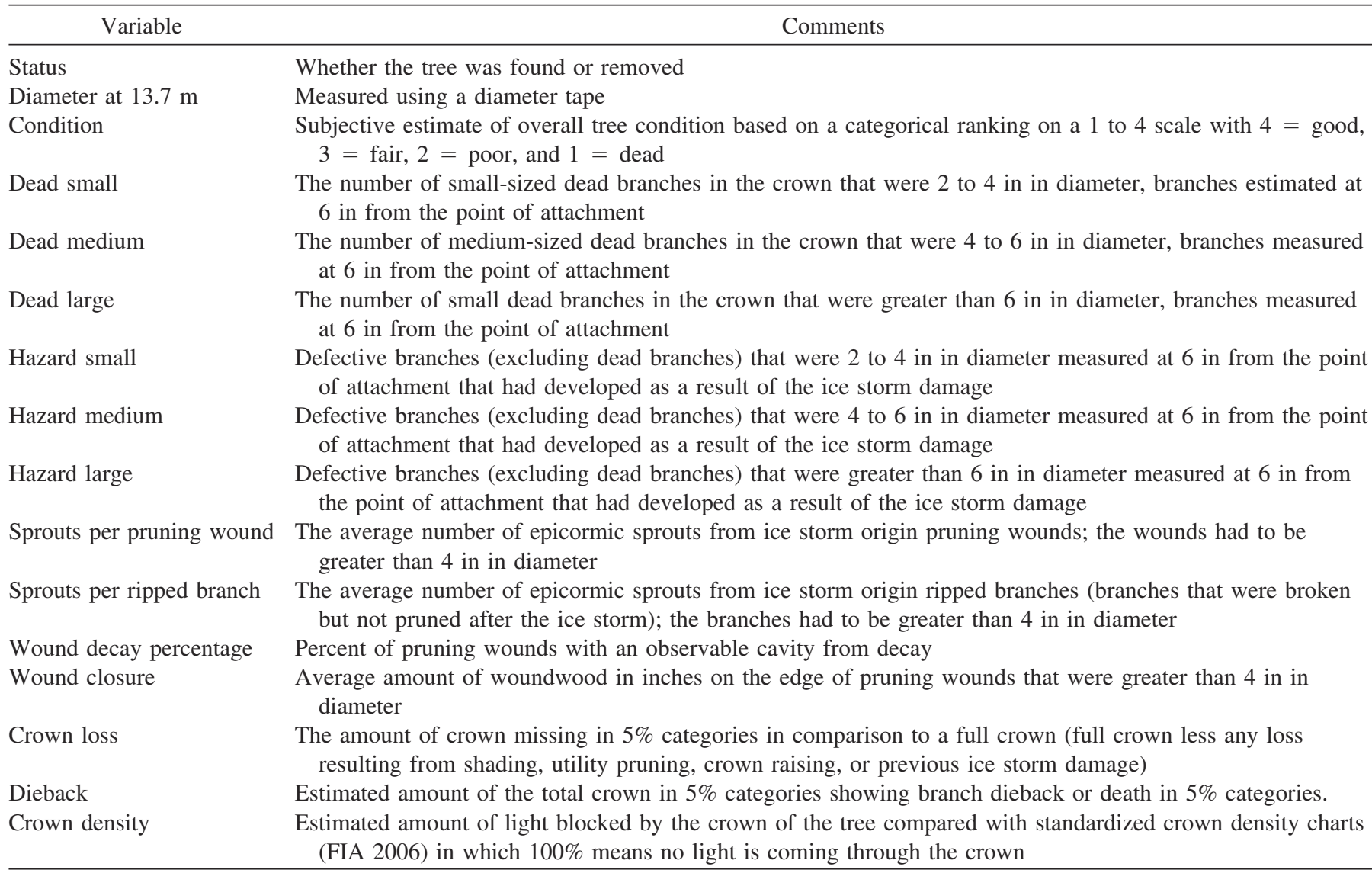


1946; Shortle et al. 2003). Data for silver and Norway maple are largely absent from the literature probably because of their low importance to rural forestry. We hypothesized from field observations of urban trees that Norway maple resprouts and compartmentalizes moderately well, whereas silver maple resprouts strongly and compartmentalizes poorly (Pokorny 2003).

This study evaluated the near-term effect (6 year postdamage) of canopy loss to common urban maples (Norway, sugar, and red and silver maples) across northern New York State that were damaged in the 1998 ice storm. These trees were evaluated originally for amount of canopy loss in 1999 and were reevaluated again in 2004 for survival, impact on tree health, and canopy response to the ice damage.

\section{MATERIALS AND METHODS}

\section{Selection of Communities and Study Trees}

The trees for this study were identified in 1999 from street trees in 22 northern New York communities from the sixcounty region (Clinton, Essex, Franklin, Jefferson, Lewis, and St. Lawrence counties) that sustained ice damage. The communities were stratified into three population size categories $(<2500,2500-11,000$, and $>11,000)$ by county, and a random selection was made such that the communities were distributed across northern New York. A sample inventory of streets from these communities that included an evaluation of ice damage to all tree species was made initially in the spring of 1999 (unpublished data).

The study population was created by assigning maples identified in the initial sample inventory to a $3 \times 3 \times 3$ matrix that consisted of maple species, diameter class at $1.37 \mathrm{~m}(4.5$ $\mathrm{ft}$ ), and ice damage category (Table 1). Ice damage category was based on visually estimated crown loss that could be specifically attributed to the recent ice storm. Initially, a category was created for trees with $50 \%$ to $75 \%$ crown loss and trees with $75 \%$ or greater crown loss. However, there were not enough trees in the highest ice damage category so 13 trees with greater than $75 \%$ crown loss were placed in the $50 \%$ or greater crown loss category for the final data analysis. Data collected on each tree in the study are presented in Table 2.

Trees were also selected from communities that were not in the original random sample to fill the sample matrix to the degree necessary. Resampling of the study trees in 2004 further reduced the sample size and distribution of trees in each

Table 3. Removal rate for tree species.

\begin{tabular}{ll}
\hline \multicolumn{1}{c}{ Species } & Removal percentage \\
\hline Norway maple & 28.3 \\
Silver and red & 24.8 \\
Sugar maple & 29.8 \\
\hline
\end{tabular}

Table 4. Removal percentage by diameter class.

\begin{tabular}{ll}
\hline \multicolumn{1}{c}{ Diameter class } & Removal percentage \\
\hline 15.2 to $45.7 \mathrm{~cm}(6-18 \mathrm{in})$ & 24.8 \\
45.7 to $76.2 \mathrm{~cm}(18-30 \mathrm{in})$ & 26.7 \\
$76.2+\mathrm{cm}(30+\mathrm{in})$ & 30.1 \\
\hline
\end{tabular}

category because some tree sites could not be relocated with confidence. Because of mistaken identification in the original data collection, red and silver maples were analyzed together, although the majority of trees (101 of 143) were silver maples.

\section{Data Collection}

Because of the scattered nature of the initial study population (47 communities in six counties), the 1999 baseline survey was carried out by a team of data collectors comprised of forest rangers of the New York State Department of Environmental Conservation, university forestry students, and the authors. The authors resurveyed the study maples alone in August 2004. All data were collected from the ground using binoculars when needed. The following data were collected on each tree.

\section{Statistical Analysis}

The data analysis for this article was generated using SAS software, Version 8.02 of the SAS System for Windows (copyright 1999 to 2001, SAS Institute Inc., Cary, NC) using the General Linear Models (GLM) procedure for analysis of variance and Tukey's studentized range for mean separations.

\section{RESULTS}

\section{Tree Removal}

Survival of the ice-damaged trees 6 years after the ice storm and 5 years after they were initially classified by species, diameter, and crown loss in this study are presented in Tables 3 to 5 . There were no significant differences in survival rates among species, diameter classes, or crown loss category. Removal rate for all categories over the 5 year period was $26.8 \%$.

\section{Tree Condition}

There was a significant difference among species for condition rating, and Norway maple had the highest and sugar maple the lowest condition rating (Table 6), but crown loss

Table 5. Removal percentage by crown loss category.

\begin{tabular}{ll}
\hline Crown loss category & Removal percentage \\
\hline $0 \%$ to $25 \%$ & 28.7 \\
$25 \%$ to $50 \%$ & 24.8 \\
$50 \%+$ & 32.4 \\
\hline
\end{tabular}


Table 6. Mean comparisons for the tree condition rating.

\begin{tabular}{ll}
\hline \multicolumn{1}{c}{ Species } & Average per tree \\
\hline Sugar maple & $3.2 \mathrm{a}$ \\
Silver maple & $3.4 \mathrm{ab}$ \\
Norway maple & $3.6 \mathrm{~b}$ \\
\hline
\end{tabular}

Condition rating in which $1=$ dead, $2=$ poor, $3=$ fair and $4=$ good. Means followed by a different letter are significantly different at $P=0.05$.

category and diameter class did not affect crown condition. None of the two- or three-way interactions among species, diameter, or crown loss were statistically significant for crown condition. Overall crown condition rating was 3.4 for all categories. Mean comparisons among species are presented in Table 6.

\section{Crown Parameters}

For dead branches, significant differences $(P=0.05)$ were found among species for small-sized branches and among the diameter categories for small-, medium-, and large-sized branches (Table 7). Larger diameter trees had more dead branches of all size categories and sugar maple contained the most dead branches and Norway maple the least. There was also a significant interaction between diameter category and maples species for large-sized branches. None of the other two- or three-way interaction among species, condition, or crown loss was statistically significant for dead branches. Overall means for the number of small-, medium-, and largesized dead branches was $0.68,0.24$, and 0.13 branches per tree, respectively.

There were no significant differences among species, condition, or crown loss categories or their interactions for any size hazardous or defective branches. The average overall species, diameter class, and crown condition categories for the number of small-, medium-, and large-sized hazardous branches per tree was $0.06,0.05$, and 0.03 , respectively. The number of wounds with observable decay was also not significantly different for any of the categories or their interac- tions. Overall, 5.4\% of the wounds had observable decay. Significant differences were found among species, diameter category, and crown loss category for the amount of wound closure (Table 8). There was also a significant species by diameter category interaction, but the three-way interaction was not significant. Overall, wound closure averaged 1.2 in per wound.

Both the number of sprouts per wound and the number of sprouts per ripped branch were significantly different among species. The number of sprouts per ripped branch was also significantly different among diameter classes. None of the two- or three-way interactions was significant for sprouts per wound or per ripped branch. Over all categories, the number of sprouts per tree averaged 0.6 and 1.1 for wounds and ripped branches, respectively. Mean comparisons for sprouts are presented in Table 9.

The crown parameters transparency and crown missing were both significant among species (Table 10). Crown missing was also significant among crown loss categories and species by diameter class interaction. Crown dieback was not significant for any of the categories. Overall, transparency, crown missing, and dieback averaged 70\%, 30\%, and 7\%, respectively. No other two- or three-way interaction was significant for these crown parameters. Mean comparisons for transparency and crown missing are presented in Table 9.

\section{DISCUSSION}

The removal rate of $26.8 \%$ over the 5 years of the study is high considering that all the study trees would be removed in less than 20 years at this rate. Federally funded removal of ice-damaged trees had been completed by the time the study was initiated and this would not have been a factor in the high removal rate. The highest rate of removal was for sugar maple and the largest diameter trees and in the highest crown loss category (Tables 4 and 5), although there was no statistical difference within these categories. The results indicate that urban tree managers can expect an elevated rate of removal after a major ice storm even after trees with the most ice damage have been removed. However, our results did not

Table 7. Mean comparisons for the significant categories found in the analysis of variance on the average number of dead small-, medium-, and large-sized branches.

\begin{tabular}{|c|c|c|c|c|c|c|c|}
\hline \multirow[b]{2}{*}{ Species } & \multicolumn{3}{|c|}{ Small dead branches } & \multicolumn{2}{|c|}{ Medium dead branches } & \multicolumn{2}{|c|}{ Large dead branches } \\
\hline & $\begin{array}{l}\text { Average } \\
\text { per tree }\end{array}$ & $\begin{array}{l}\text { Diameter } \\
\text { category }\end{array}$ & $\begin{array}{l}\text { Average } \\
\text { per tree }\end{array}$ & $\begin{array}{l}\text { Diameter } \\
\text { category }\end{array}$ & $\begin{array}{l}\text { Average } \\
\text { per tree }\end{array}$ & $\begin{array}{l}\text { Diameter } \\
\text { category }\end{array}$ & $\begin{array}{l}\text { Average } \\
\text { per tree }\end{array}$ \\
\hline Sugar maple & $1.18 \mathrm{a}$ & $\begin{array}{c}15.2 \text { to } 45.7 \mathrm{~cm} \\
(6-18 \text { in })\end{array}$ & $0.31 \mathrm{a}$ & $\begin{array}{l}15.2 \text { to } 45.7 \mathrm{~cm} \\
(6-18 \mathrm{in})\end{array}$ & $0.10 \mathrm{a}$ & $\begin{array}{l}15.2 \text { to } 45.7 \mathrm{~cm} \\
(6-18 \mathrm{in})\end{array}$ & $0.02 \mathrm{a}$ \\
\hline Silver maple & $0.59 \mathrm{ab}$ & $\begin{array}{l}45.7 \text { to } 76.2 \mathrm{~cm} \\
(18-30 \mathrm{in})\end{array}$ & $0.77 \mathrm{ab}$ & $\begin{array}{l}45.7 \text { to } 76.2 \mathrm{~cm} \\
(18-30 \mathrm{in})\end{array}$ & $0.22 \mathrm{ab}$ & $\begin{array}{l}45.7 \text { to } 76.2 \mathrm{~cm} \\
(18-30 \mathrm{in})\end{array}$ & $0.11 \mathrm{ab}$ \\
\hline Norway maple & $0.26 \mathrm{~b}$ & $\begin{array}{l}76.2+\mathrm{cm} \\
(30+\text { in })\end{array}$ & $1.19 \mathrm{~b}$ & $\begin{array}{l}76.2+\mathrm{cm} \\
\quad(30+\mathrm{in})\end{array}$ & $0.55 \mathrm{~b}$ & $\begin{array}{l}76.2+\mathrm{cm} \\
(30+\mathrm{in})\end{array}$ & $0.36 \mathrm{~b}$ \\
\hline
\end{tabular}

Means followed by a different letter are significantly different at $P=0.05$. 
Table 8. Mean comparisons for significant categories found in the analysis of variance on the amount of wound closure per wound.

\begin{tabular}{llllll}
\hline Species & $\begin{array}{l}\text { Average inches } \\
\text { per wound }\end{array}$ & Diameter category & $\begin{array}{l}\text { Average inches } \\
\text { per wound }\end{array}$ & $\begin{array}{l}\text { Crown loss } \\
\text { category }\end{array}$ & $\begin{array}{l}\text { Average inches } \\
\text { per wound }\end{array}$ \\
\hline Sugar maple & $0.91 \mathrm{a}$ & 15.2 to $45.7 \mathrm{~cm}(6-18 \mathrm{in})$ & $1.4 \mathrm{a}$ & $0 \%$ to $25 \%$ & $1.4 \mathrm{a}$ \\
Silver maple & $1.2 \mathrm{ab}$ & 45.7 to $76.2 \mathrm{~cm}(18-30 \mathrm{in})$ & $1.1 \mathrm{~b}$ & $25 \%$ to $50 \%$ & $1.3 \mathrm{ab}$ \\
Norway maple & $1.5 \mathrm{~b}$ & $76.2+\mathrm{cm}(30+\mathrm{in})$ & $1.1 \mathrm{~b}$ & $50 \%+$ & $1.0 \mathrm{~b}$ \\
\hline
\end{tabular}

Means followed by a different letter are significantly different at $P=0.05$.

elucidate what factor(s) were causing this elevated removal rate. Anecdotal evidence during the field survey suggested that at least some study trees were removed as a result of highway construction.

Study of ice damage to trees shortly after a storm has clearly demonstrated that species are damaged differentially by ice loading. For example, sugar maple is usually ranked as intermediate in susceptibility to ice damage, whereas silver maple is rated as susceptible (Hauer et al. 1994; Sisinni et al. 1995). This study shows that there is also a differential species response to ice damage. Shortle et al. (2003) also found a differential species response in forest trees. Based on our results, sugar maple was in poorer condition (Table 6), had greater number of small dead branches (Table 7), less wound closure (Table 8), and fewer sprouts per wound and ripped branch (Table 9) than Norway and silver maple. These data suggest that sugar maple is responding less favorably to the crown loss than are the other maple species, similar to what has been found for rural trees (Spaulding and Bratton 1946).

Initial ice-induced crown loss was a significant factor only in the amount of wound closure (Table 8). These results suggest that crown loss is less significant in tree response than species or diameter class for the crown parameters that were measured. Sisinni et al. (1995) suggested that the location of crown loss in the tree was as important the amount of crown loss. For example, trees with peripheral branch damage on the outside of the crown were suggested to have greater chances for recovery than if the damage extended into larger scaffolds or the main trunk. The type and location of crown loss damage was not classified in this study, but it could be a significant factor affecting survival and the other parameters that we measured.

Diameter class was found to be significant for the number of small- and medium-sized dead branches (Table 7), amount of wound closure (Table 8), and the number of sprouts per ripped branch (Table 9). In general, there were more dead branches, less wound closure, and fewer sprouts in largersized trees. These results suggest that larger diameter trees (greater than 30 in in diameter) will respond less favorably in certain crown parameters than smaller diameter trees.

This study is short term in nature because trees were assessed 6 years after the initial damage. This timeframe seems adequate for short-term effects to appear such as initial decay (Campbell and Davidson 1940) and decline or dieback as a result of secondary pest attack (Wargo and Harrington 1991; Shortle et al. 2003). The timeframe is likely not adequate for longer-term effects such as extensive wood decay (Campbell 1937) or development of hazardous branches resulting from poorly attached or decayed sprouts. Current FEMA guidelines allow for reimbursement for removal of ice-damaged trees based on crown loss levels alone. In a federally declared disaster, public trees with greater than 50\% crown loss are eligible for reimbursement. Our study did not provide evidence that crown loss alone is a good parameter on which to base removal recommendations on. Furthermore, Shortle et al. (2003) also found that species response is important in recovery from ice damage in forested situations. Based on these results, urban tree managers should also consider other parameters such as tree species and diameter class before making final removal judgments on individual trees, because individual species will react differently to ice damage. For example, based on our results, sugar maples appear less likely to resprout and are more likely to be in poorer condition with more dead branches after six years.

Finally, although nearly $25 \%$ of the original study population was removed, the remaining $75 \%$ showed little shortterm negative effect of the ice damage. The short duration of the study could not provide adequate answers to how ice-

Table 9. Mean comparisons for the significant categories found in the analysis of variance on the sprouts per wound and ripped branches.

\begin{tabular}{llllll}
\hline Species & $\begin{array}{l}\text { Average number } \\
\text { per wound }\end{array}$ & Species & $\begin{array}{l}\text { Average number } \\
\text { per ripped branch }\end{array}$ & Diameter category & $\begin{array}{l}\text { Average number } \\
\text { per ripped branch }\end{array}$ \\
\hline Sugar maple & $0.1 \mathrm{a}$ & Sugar maple & $0.1 \mathrm{a}$ & 15.2 to $45.7 \mathrm{~cm}(6-18 \mathrm{in})$ & $1.6 \mathrm{a}$ \\
Silver maple & $1.0 \mathrm{~b}$ & Silver maple & $1.6 \mathrm{~b}$ & 45.7 to $76.2 \mathrm{~cm}(18-30 \mathrm{in})$ & $0.8 \mathrm{~b}$ \\
Norway maple & $0.5 \mathrm{ab}$ & Norway maple & $1.1 \mathrm{~b}$ & $76.2+\mathrm{cm}(30+\mathrm{in})$ & $0.9 \mathrm{ab}$ \\
\hline
\end{tabular}

Means followed by a different letter are significantly different at $P=0.05$. 
Table 10. Mean comparisons for the significant categories found in the analysis of variance on the crown transparency and crown loss.

\begin{tabular}{llllll}
\hline Species & $\begin{array}{l}\text { Average crown } \\
\text { transparency }\end{array}$ & Species & $\begin{array}{l}\text { Average crown } \\
\text { missing }\end{array}$ & $\begin{array}{l}\text { Crown loss } \\
\text { category }\end{array}$ & $\begin{array}{l}\text { Average crown } \\
\text { missing }\end{array}$ \\
\hline Sugar maple & $73 \mathrm{a}$ & Sugar maple & $33 \mathrm{a}$ & $0 \%$ to $25 \%$ & $14 \mathrm{a}$ \\
Silver maple & $63 \mathrm{~b}$ & Silver maple & $36 \mathrm{a}$ & $25 \%$ to $50 \%$ & $40 \mathrm{~b}$ \\
Norway maple & $82 \mathrm{a}$ & Norway maple & $19 \mathrm{~b}$ & $50 \%+$ & $68 \mathrm{~b}$ \\
\hline
\end{tabular}

Means followed by a different letter are significantly different at $P=0.05$.

damaged trees will survive over the long run. Clearly, this information is still needed to provide urban tree managers with more definitive answers on how to manage ice-damaged trees.

Acknowledgments. The original survey of communities that this research is based on was conducted by Jerry Bond while Community Forester at Monroe County Cooperative Extension, Rochester, NY, with funding from the New York State

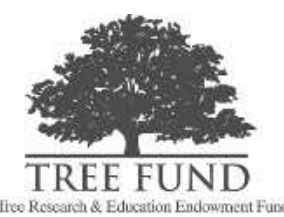
Department of Environmental Conversation through an award of funds from the Federal Emergency Appropriation for ice storm recovery. The follow-up survey was funded by a TREE Fund Hyland Johns grant, for which the authors gratefully acknowledge the support.

\section{LITERATURE CITED}

Bruederle, L.P., and F.W. Sterns. 1985. Ice storm damage to a southern Wisconsin mesic forest. Bulletin of the Torrey Botanical Club 112:167175.

Campbell, W.A. 1937. Decay hazard resulting from ice damage to northern hardwoods. Journal of Forestry 35: 1156-1158.

Campbell, W.A., and R.W. Davidson. 1940. Top rot in glazedamaged black cherry and sugar maple on the Allegheny plateau. Journal of Forestry 38:963-965.

Carvall, K.L., E.H. Tyron, and R.P. True. 1957. Effects of glaze on the development of Appalachian hardwoods. Journal of Forestry 55:130-132.

Croxton, W.C. 1939. A study of the tolerance of trees to breakage by ice accumulation. Ecology 20:71-73.

Downs, A.A. 1938. Glaze damage in the birch-beech-maplehemlock type in Pennsylvania and New York. Journal of Forestry 36:63-70.

FEMA. 1999. Public Assistance: Debris Management Guide. FEMA Publication 325. http://www.fema.gov/grant/pa/ dmgtoc.shtm (accessed 8/16/06).

- 2006. Disaster information. http://www.fema.gov/ hazard (accessed 8/16/06).

FIA. 2006. FIA Field Methods for Phase 3 Measurements, 2006. http://fia.fs.fed.us/library/field-guides-methodsproc (accessed 8/16/06).
Hauer, R.W., W. Wand, and J.O. Dawson. 1993. Ice damage to urban trees. Journal of Arboriculture 19:187-194. http://www.na.fs.fed.us/spfo/pubs/uf/sotuf/chapter_4/ appendix_b/appendixb.htm (accessed 7/1/06).

Hauer, R.J., M.C. Hruska, and J.O. Dawson. 1994. Trees and Ice Storms: The Development of Ice-Storm Resistant Urban Tree Populations. Special Pub. 94-1, Department of Forestry, University of Illinois at Urbana-Champaign. Urbana, IL. 12 pp.

Irland, L.C. 1998. Ice storm 1998 and the forests of the Northeast. A Preliminary Assessment. Journal of Forestry 96:32-40.

Lemon, P.C. 1961. Forest ecology of ice storms. Bulletin of the Torrey Botanical Club 88:21-29.

Melancon, S. and M.J. Lechowicz. 1987. Differences in the damage caused by glaze ice on codominant Acer saccharum and Fagus grandifolia. Canadian Journal of Botany 65:1157-1159.

Pokorny, J. 2003. Urban Tree Management: A Community Guide to Program Design and Implementation. USDA Forest Service, Northeastern Area, State and Private Forestry, St. Paul, MN. NA-TP-03-03. http://www.na.fs.fed. us/spfo/pubs/uf/utrmm/ (accessed 8/16/06).

Seischab, F.K., J.M. Bernard, and M.D. Eberle. 1993. Glaze damage to western New York forest communities. Bulletin of the Torrey Botanical Club 120:64-72.

Shortle, W.C., and K.T. Smith. 1998a. Prospects for recovery. In Ice Storm 1998 and the Forests of the Northeast. Irland, L.C. (coordinator). Journal of Forestry 96:32-40.

- 1998b. How to determine percent live crown loss in hardwoods before leaf-out. In Ice Storm 1998. USDA Forest Service Information Sheet \#1, Durham, NC. http:// www.fs.fed.us/na/durham/ice/public/pub_file/is_fs_ 01.pdf (accessed 8/1/06).

Shortle, W.C., K.T. Smith, and K.R. Dudzik. 2003. Tree Survival and Growth Following Ice Storm Injury. Research Paper NE-723. USDA Forest Service, Northeastern Research Station, Newtown Square, PA.

Sisinni, S.M., W.C. Zipperer, and A.G. Pleninger. 1995. Impacts from a major ice storm: Street tree damage in Rochester, NY. Journal of Arboriculture 21:156-167. 
Smith, K., and W.C. Shortle. 2003. Radial growth of hardwoods following the 1998 ice storm in New Hampshire and Maine. Canadian Journal of Forest Research 33:325-329. http://www.fs.fed.us/ne/durham/4505/ papers/SmithandShortle2003.pdf (accessed 7/15/06).

Spaulding, P., and A.W. Bratton. 1946. Decay following glaze damage in woodlands of central New York. Journal of Forestry 44:515-519.

Van Dyke, O. 1999. A literature review of ice storm impacts in Eastern North America. Ontario Ministry of Natural Resources, Southcentral Sciences Section, North Bay Ontario. Technical Report \#112. http://isfratt.eomf.on.ca/ pdfs/litrvw.pdf (accessed 8/16/06).

Wargo, P.M., and T.C. Harrington. 1991. Host stress and susceptibility. Chapter 7, In Armillaria Root Disease. Agricultural Handbook No. 691. USDA Forest Service, Washington, DC. 233 pp.

Christopher J. Luley (corresponding author)

Urban Forestry LLC

6050 Hicks Rd.

Naples, NY 14512, U.S.

chris@urbanforestryllc.com

\section{Jerry Bond}

Davey Resource Group

3904 Willowdale Lane

Geneva NY 14456-9267, U.S.

Zusammenfassung. Die alljährlichen Eisstürme verursachen in Kanada und den USA Schäden in Millionenhöhe an Straßenbäumen und Infrastruktur. Dennoch gibt es nur unzureichend Informationen, die Entscheidungen zum Entfernen von geschädigten Bäumen begünstigen. Diese Studie beschäftigt sich mit drei Acer-Arten, die 1998 bei Stürmen im Bundesstaat New York beschädigt wurden. Acer platanoides, A. saccharinum und A. saccharum wurden in einen von drei Durchmesserklassen und Kategorien des Kronenverlustes platziert und 6 Jahre nach dem ersten Schaden bewertet. Es gab keine Differenzen unter den Arten, Kronenverlust oder Durchmesserklasse bei den entfernten Bäumen, die etwa $26.5 \%$ über die 5 Jahre betrugen. Analysen der Anzahl von Gesundheit- und Kronenparameter zeigten, dass die Baumart den wichtigsten Faktor darstellt, während Durchmesser und Kronenverlust weniger wichtig waren. Diese Ergebnisse verdeutlichen, dass urbane Baumverantwortliche die Baumart als einen wesentlichen Faktor bei den Fällungsentscheidungen nach einem Eissturm in Betracht ziehen sollten.

Resumen. Anualmente las tormentas de nieve causan millones de dólares en daños a los árboles urbanos y a la infraestructura en los Estados Unidos y Canadá. Sin embargo, existe limitada información para orientar la jurisprudencia acerca de la remoción de los árboles afectados. Este estudio siguió la respuesta de tres especies de maple que fueron dañados por la tormenta de nieve en 1998 en el norte del estado de Nueva York. Acer platanoides, A. saccharinum y A. saccharum fueron clasificados en tres clases diamétricas y categorías de pérdida de copa y fueron revaluados seis años después del daño inicial. No hubo diferencias entre especies, pérdida de copa o clase diamétrica para los árboles removidos, que promediaron $26.8 \%$ en los 5 años. El análisis de variación de los árboles saludables y los parámetros de copa mostraron que las especies de árboles fueron los factores más importantes en la respuesta, mientras que clase diamétrica y pérdida de copa fueron los menos importantes. Estos resultados sugieren que los manejadores de árboles urbanos deberían considerar las especies de árboles como un factor importante en las decisiones de remoción después de una tormenta. 